\title{
Analiza normativnog okvira za sprječavanje zakonitog izbjegavanja poreza u Hrvatskoj: prijedlog izmjena u skladu s pravom Europske unije
}

Gadžo, Stjepan; Klemenčić, Irena

Source / Izvornik: Odabrani prijevodi, 2014, 5, 1 - 19

Journal article, Published version

Rad u časopisu, Objavljena verzija rada (izdavačev PDF)

https://doi.org/10.3326/op.25

Permanent link / Trajna poveznica: https://urn.nsk.hr/urn:nbn:hr:242:124284

Rights / Prava: Attribution-NonCommercial-NoDerivatives 4.0 International/ImenovanjeNekomercijalno-Bez prerada 4.0 međunarodna

Download date / Datum preuzimanja: 2023-04-26

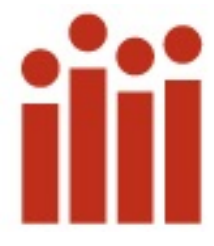

Repository / Repozitorij:

Institute of Public Finance Repository

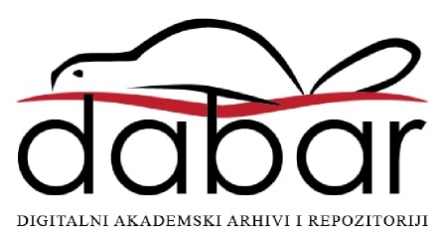


Institut za

javne financije

Smičiklasova 2I | Zagreb

www.ijf.hr | ured@ijf.hr

T: oI/4886-444 | F: OI/48I9-365

\section{OdABRANI}

\section{PRIJEVODI}

ISSN I847-7445

BR. 25/I4

citirati: Gadžo, S. i Klemenčić, I. 2OI4. Time to stop avoiding the tax avoidance issue in Croatia? A proposal based on recent developments in the European Union. Financial Theory and Practice, 38 (3), str. 277-302.

http://fintp/upload/files/ftp/20I4/ 3/gadzo_klemencic.pdf

Svi Odabrani prijevodi dostupni su na: http://www.ijf.hr/hr/publikacije/ca sopisi/I2/odabrani-prijevodi/III/

\section{ANALIZA NORMATIVNOG OKVIRA ZA SPRJEČAVANJE ZAKONITOG IZBJEGAVANJA POREZA U HRVATSKOJ: PRIJEDLOG IZMJENA U SKLADU S PRAVOM EUROPSKE UNIJE}

\author{
MAG. IUR. STJJEPAN GADŽO* \\ MAG. IUR. IRENA KLEMENČIĆ*
}

\author{
PREGLEDNI RAD ${ }^{* *}$ \\ JEL: K34 \\ DOI: $10.3326 /$ op.25
}

\section{SAŽETAK}

U ovom se radu, uzimajući u obzir više ciljeva porezne politike, analizira pristup izbjegavanju poreza u Hrvatskoj te ukazuje na njegove postojeće nedostatke. Ističe se kako Hrvatska tek treba razviti koherentan normativni okvir za sprječavanje izbjegavanja poreza. U tom smislu posebno se ističe nedostatak općeg pravila protiv izbjegavanja poreza, ključnog instrumenta poreznih sustava mnogih svjetskih država. Autori predlažu uvođenje općeg pravila u hrvatsko porezno zakonodavstvo, polazeći od aktualnih prijedloga i inicijativa institucija Europske unije (EU). Prijedlog je usklađen s više ciljeva porezne politike. Pritom se posebno naglašava načelo pravne sigurnosti, koje je dosad zanemareno u dinamici razvoja hrvatskog poreznog sustava. Također, autori ističu kako ovu analizu valja razmatrati u kontekstu posljednje ekonomske krize, koja dodatno nameće potrebu za stvaranjem održivog sustava javnih financija.

Ključne riječi: izbjegavanje poreza, opće pravilo protiv izbjegavanja poreza, GAAR, porezno pravo Europske unije, umjetne transakcije, porezna politika

Autori zahvaljuju trojici anonimnih recenzenata na njihovim korisnim komentarima i savjetima. "Primljeno: 23. svibnja 2014.

Prihvaćeno: II. srpnja 2014.

Prijašnja verzija ovog rada predstavljena je na konferenciji Instituta za javne financije, Ekonomskog fakulteta u Zagrebu te Ekonomskog fakulteta u Rijeci Tax Reforms: Experiences and Perspectives koja je održana u Zagrebu 20. lipnja 2014.

Stjepan GADŽO

Pravni fakultet Sveučilišta u Rijeci, Hahlić 6, 5Iooo Rijeka, Hrvatska e-mail: sgadzo@pravri.hr

Irena KLEMENČIĆ

Institut za javne financije, Smičiklasova 2I, IOooo Zagreb, Hrvatska e-mail: irena.klemencic@ijf.hr 


\section{UVOD}

"Izbjegavanje poreza jedina je intelektualna aktivnost koja još uvijek nosi neku nagradu."

(J.M. Keynes) ${ }^{\mathrm{I}}$

Još od sveobuhvatne porezne reforme iz 1994. godine, hrvatski porezni sustav obilježava manjak sustavnog pristupa problemu izbjegavanja poreza. Iako je hrvatski zakonodavac pratio globalne trendove pri usvajanju brojnih tzv. posebnih pravila protiv izbjegavanja poreza (engl. targeted antiavoidance rules; TAARs; u daljnjem tekstu: posebna pravila), uočljiv je nedostatak onih zakonodavnih pravila kojima se mogu suzbiti složenije strukture poreznih obveznika smišljene s ciljem izbjegavanja plaćanja poreza, tzv. općih pravila protiv izbjegavanju poreza (engl. General Anti Avoidance Rule; GAARs; u daljnjem tekstu: opća pravila). Uslijed sve izraženije percepcije javnosti kako bogati pojedinci i multinacionalne korporacije (MNK-i) ne plaćaju "pravedni udio" u financiranju javnih usluga, veći broj država u posljednje je vrijeme posegnuo za uvođenjem općih pravila (Ernst \& Young, 2013.). Sastanci međunarodnih foruma suradnje poput G8 i G2o iz 2013. godine, kao i druge aktualnosti na globalnoj razini (npr. projekt OECD-a protiv erozije porezne osnovice i premještanja dobiti) ukazuju da je izbjegavanje poreza trenutno jedno od najvažnijih pitanja u svijetu oporezivanja.

Inicijativa ne manjka niti na razini Europske unije, čije institucije naglašavaju potrebu za uniformnim pristupom izbjegavanju poreza u svim državama članicama. Jedan od temeljnih elemenata ovog pristupa jest i tzv. "opće pravilo EU-a", predloženo u neobvezujućoj preporuci Europske komisije (EK) iz 20I2. godine. Predloženo se pravilo temelji na praksi Suda EU-a, koja je uvelike utjecala na unutarnje pravo država članica. S obzirom na ograničenu nadležnost institucija EU-a u poreznim stvarima, utjecaj navedenog prijedloga ovisit će o izborima nositelja porezne politike svake pojedine države članice.

U ovom se radu, polazeći od ciljeva porezne politike, tvrdi kako bi u hrvatski porezni sustav trebalo uvesti opće pravilo, oblikovano u skladu s preporukom EK-a. Argumenti u prilog navedene teze sežu i izvan tradicionalne rasprave o utjecaju općeg pravila na pravednost i učinkovitost, temeljne ciljeve porezne politike. U doba fiskalne konsolidacije iznimno je značajan potencijal općeg pravila kao oruđa za smanjenje poreznog jaza. S jedne strane, ono može u određenoj mjeri nadoknaditi one javne prihode izgubljene zbog izbjegavanja poreza, a s druge može voditi unaprjeđenju opće razine dobrovoljnog ispunjavanja poreznih obveza. Sukladno tomu, uvođenje općeg pravila daje jasan signal tržištima kapitala da javna vlast ima odgovoran pristup nametanju i prikupljanju poreza, što je jedan od nužnih preduvjeta za održivost javno-financijskog sustava. Ovaj argument od posebne je važnosti s obzirom da se hrvatski sustav javnih financija trenutno nalazi u postupku nadzora od strane institucija EU-a. Nadalje se ističe kako bi uvođenje općeg pravila moglo imati pozitivne učinke na ostvarenje načela pravne sigurnosti, važnog za sve dionike u Hrvatskoj, napose kad bi se paralelno uveli i drugi instrumenti usmjereni jačanju odnosa između poreznih tijela i poreznih obveznika (npr. institut obvezujućeg mišljenja).

Rad je podijeljen na pet dijelova. Nakon uvoda, u drugom se dijelu naglašava važnost problema izbjegavanja poreza za oblikovanje porezne politike, kao i uloga općeg pravila u tom kontekstu. U trećem se dijelu opisuje dodana složenost vođenja politike protiv izbjegavanja poreza u državama članicama EU-a. Također se izlažu osnovne postavke prijedloga EK-a o uvođenju jedinstvenog općeg pravila te se daje kratak pregled iskustava koje su odabrane države članice, pogođene negativnim

${ }^{\mathrm{I}}$ Citat prenesen iz Perrou (2006.). 
učincima posljednje ekonomske krize (Španjolska, Italija i Portugal), dosad imale s općim pravilima. Četvrti se dio bavi dosadašnjim pristupom ovom problemu u Hrvatskoj te sadrži prijedlog o uvođenju općeg pravila u hrvatski porezni sustav. Peti dio sadrži kratak pregled osnovnih nalaza rada.

\section{SPRJEǦAVANJE IZBJEGAVANJA POREZA I ULOGA OPǴEG PRAVILA}

Porezna se politika sastoji od mnogostrukih izbora $u$ vezi porezne strukture i porezne tehnike. Iz normativne se perspektive ove odluke, kao i njihovi učinci, tradicionalno evaluiraju pomoću tri kriterija: kriterija pravednosti, kriterija učinkovitosti i kriterija administrativne provedivosti (Avi Yonah, 2006.). Drugim riječima, nositelji porezne politike moraju istovremeno težiti stvaranju onog poreznog sustava koji je u što većoj mogućoj mjeri pravedan, učinkovit i jednostavan. U teoriji je javnih financija ustanovljeno kako na ostvarenje navedenih ciljeva utječe i ponašanje poreznih obveznika (Slemrod i Yithzaki, 2002.). U svakoj državi postoji određeni postotak poreznih obveznika koji ne udovoljavaju svojim poreznim obvezama. Stupanj udovoljavanja poreznoj obvezi složen je problem koji se ne može pojasniti isključivo pomoću čimbenika poput visine kazni i vjerojatnosti otkrivanja djela (Alm, 2012.). Drugi čimbenici, kao što su porezni moral i društvene norme, također su važni (Torgler i Schaltegger, 2006.). Iako rasprava o mogućim uzrocima neispunjavanja poreznih obveza prelazi granice ovog rada, njihovo razumijevanje od ključne je važnosti za nositelje porezne politike (Tooma, 2008.)2.

\section{I. O KONCEPTU IZBJEGAVANJA POREZA I ULOZI PRAVA U "GRTANJU GRANICA"}

Valja razlikovati dvije osnovne vrste neispunjavanja poreznih obveza, i to s obzirom na njihove pravne implikacije: (I) nezakonito izbjegavanje poreza ili poreznu utaju, te (2) zakonito izbjegavanje poreza ${ }^{3}$. Dok se poreznom utajom označava ponašanje koje je nezakonito, tj. protivno slovu (poreznog) zakona, zakonito je izbjegavanje poreza u skladu je sa slovom (poreznog) zakona, ali je protivno cilju primjenjivih odredbi ${ }^{4}$. Poreznu je utaju puno lakše prepoznati, unutar širokog spektra protuzakonitih aktivnosti koje porezni obveznici poduzimaju s ciljem umanjenja vlastite porezne obveze. Tipični su primjeri neprijavljivanje čitavog dohotka za svrhe oporezivanja, izdavanje lažnih računa za potrebe poreza na dodanu vrijednost ili lažno umanjenje vrijednosti imovine (Alm, 20I2.). Suprotno tomu, kvalifikacija određenog ponašanja kao zakonitog izbjegavanja poreza predstavlja izazov i za porezna tijela i za same porezne obveznike. Posljedica je to inherentne neodređenosti i dvosmislenosti ovog pojma, pogotovo kad se usporedi s konceptima "poreznog planiranja" ili "minimizacije poreznih obveza". S obzirom da je cilj ovog rada dati prijedlog za suprotstavljanje zakonitom izbjegavanju poreza pomoću zakonodavnih instrumenata, korisno je započeti s pokušajem pojmovnog određenja ove pojave.

Za početak valja uočiti kako porezni obveznici na raspolaganju imaju čitav niz izbora i odluka koji izravno utječu na visinu njihove porezne obveze. U tom smislu, jedno od općih obilježja poreznih sustava jest ovisnost porezne obveze o "ekonomskoj stvarnosti koja je prethodno bila regulirana, klasificirana ili kvalificirana u drugim granama prava (npr. normama trgovačkog prava ili koje druge privatno-pravne grane)" (Ruiz Almendral, 2005.). Dakle, porezni obveznici načelno imaju slobodu odabira pravnog oblika vlastitih ekonomskih aktivnosti, što može u bitnome utjecati na visinu poreznog duga. Tipični primjeri uključuju izbor financiranja poslovne djelatnosti pomoću vlastitog kapitala ili duga te opciju obavljanja poslovne djelatnosti u korporativnoj formi. Porezno je planiranje širok pojam

\footnotetext{
${ }^{2}$ Za sveobuhvatnu studiju uzroka neispunjavanja poreznih obveza vidi Andreoni, Erard i Feinstein (I998.).

${ }^{3} \mathrm{U}$ hrvatskom prijevodu ovog rada, izvorno pisanog na engleskom jeziku, namjerno se izostavlja pojam "porezne evazije". Naime, hrvatsko nazivlje financijskog prava, za razliku od engleskog (tax evasion), ovim pojmom obuhvaća obje navedene vrste neispunjavanja poreznih obveza.

${ }^{4}$ Za detaljniji uvid u ovu dihotomiju vidjeti Uckmar (1983.).
} 
kojim se označava cijeli spektar zakonitih aktivnosti usmjerenih umanjenju ili odgodi porezne obveze, tj. optimizaciji porezne pozicije određene osobe. S druge strane, izbjegavanje poreza uključuje one aktivnosti poreznog planiranja koje se iz nekog razloga smatraju "nelegitimnima" ili "neprihvatljivima" (Russo, 2007.). S ciljem jasnoće prikaza pojam poreznog planiranja infra se upotrebljava isključivo u vezi s onim aktivnostima koje su, sa stajališta nositelja porezne politike, prihvatljive i dopuštene (Atkinson, 2OI2.).

Valja naglasiti kako pokušaji preciznog definiranja izbjegavanja poreza zapravo niti nemaju preveliko značenje za nositelje porezne politike. Naime, naglasak mora biti na "crtanju granice" između (prihvatljivog) poreznog planiranja i (neprihvatljivog) izbjegavanja poreza. U tom smislu ističu se dva aspekta: prvo, pitanje kriterija koje pritom valja primijeniti te, drugo, pitanje institucionalne nadležnosti za razvoj kriterija razgraničenja. Prvi aspekt obično uključuje analizu svrhe pravnih konstrukcija poreznog obveznika, koja se može ustanoviti pomoću subjektivnih ili objektivnih faktora (Zimmer, 2002.). Sukladno tomu, aktivnosti čiji je jedini ili glavni cilj stjecanje porezne pogodnosti, što je suprotno svrsi primjenjivog prava, prelaze granicu izbjegavanja poreza (Cooper, 200I.). Potonji se aspekt odnosi na ulogu zakonodavne i sudske grane vlasti u uspostavljanju i razvoju doktrina usmjerenih protiv izbjegavanja poreza. U nekim su državama, napose onima koje pripadaju common law pravnom krugu (npr. Ujedinjeno Kraljevstvo, SAD), sudovi zauzeli aktivnu ulogu sa zavidnim stupnjem slobode i kreativnosti u razgraničenju pojma izbjegavanja poreza (Brown, 2OI2.). U drugim državama, i to ne samo u onima koje pripadaju kontinentalnom pravnom krugu (npr. Belgija, Njemačka, Švedska), uloga je sudova ograničena, uglavnom temeljem ustavnih ograničenja moći oporezivanja (Zimmer, 2002.; Vanistaendel, I996.). Ova je spoznaja vrlo važna za nositelje porezne politike, s obzirom da na donošenje odluke o uporabi zakonodavnih instrumenata za sprječavanje izbjegavanja poreza uvelike utječe procijenjeni stupanj učinkovitosti sudske prakse iz ovog područja (Arnold, 2008.).

Bez obzira na odabrani pristup, nekoliko je razloga zbog kojih zakonito izbjegavanje poreza mora biti prepoznato kao važno porezno-političko pitanje. Ponajprije stoga što ono ugrožava ostvarenje temeljnih ciljeva porezne politike. Izbjegavanje poreza sužava poreznu osnovicu i mijenja relativne udjele poreznog opterećenja između poreznih obveznika (Tax Law Review Committee, 1997.), i to, obično na štetu skupina s nižim dohocima (Hillman, 2009.). To podriva ostvarenje načela pravednosti. Sa stajališta ekonomske učinkovitosti, izbjegavanje poreza izaziva nepotrebne društvene troškove, s obzirom da iskrivljuje odluke, koje se ne donose samo temeljem graničnog društvenog troška i koristi određene ekonomske aktivnosti (Hyman, 20II.). Nadalje, pojava novih tehnika izbjegavanja poreza rezultira i povećanom složenosti poreznog zakonodavstva, s obzirom na napore zakonodavca da se zatvore pojedine "rupe u zakonu" (Tax Law Review Committee, 1997.). To neupitno dovodi do povećanih troškova oporezivanja, i administrativnih i onih vezanih uz udovoljavanje poreznoj obvezi.

Također, u post-kriznom razdoblju fiskalne konsolidacije, drugi negativni učinci izbjegavanja poreza u fokusu su zanimanja nositelja porezne politike. Izravni makroekonomski učinak izbjegavanja poreza jest gubitak javnih prihoda (Tooma, 2008.), što je od posebne važnosti za sve države koje se istovremeno suočavaju s rastućim proračunskim manjkovima i ograničenjima daljnjeg zaduživanja. Sukladno tomu, jačanje instrumenata usmjerenih sprječavanju izbjegavanja poreza predstavlja dio strategije širenja porezne osnovice, neophodne za poduzimanje procesa fiskalne konsolidacije na prihodovnoj strani (International Monetary Fund, 20I3.). Konačno, ne može se zanemariti niti činjenica da su nositelji političkih procesa postali svjesni negativne percepcije javnosti koju izbjegavanje poreza izaziva, posebno jer se smatra privilegijom bogatih pojedinaca i MNK-a (Freedman, 20I2.). Borba protiv ove 
pojave trenutno je jedno od gorućih pitanja koja se rješavaju u radu brojnih multilateralnih organizacija i foruma suradnje (npr. G2o, OECD, EU) te posljednje razdoblje obilježava rastući stupanj međudržavne suradnje u ovom području.

\subsection{OPĆE PRAVILO KAO INSTRUMENT PROTIV ZAKONITOG IZBJEGAVANJA POREZA}

Zakonodavni instrumenti namijenjeni suprotstavljanju zakonitom izbjegavanju poreza dijele se $u$ dvije skupine: (I) tzv. posebna pravila, i (2) tzv. opća pravila. Porezni sustavi većeg broja država sadrže obje vrste instrumenata (Ernst \& Young, 2013.). Glavna je razlika u njihovom opsegu primjene, tj. u vrsti ponašanja protiv kojeg su usmjereni. Posebna su pravila namijenjena sprječavanju specifičnih struktura zakonitog izbjegavanja poreza, poput transfernih cijena ili potkapitalizacije. S druge strane, opća pravila imaju puno širi opseg primjena te čine svojevrsnu "zaštitnu mrežu" protiv izbjegavanja poreza (Ostwal i Vijaraghavan, 20Io.). Temeljna je uloga općeg pravila označiti zakonsku granicu između prihvatljivog poreznog planiranja i neprihvatljivog izbjegavanja poreza, i to tako da se poreznim tijelima i sudovima na raspolaganje stavi niz kriterija koje moraju uzeti u obzir prilikom odlučivanja o prihvatljivosti specifičnog ponašanja poreznog obveznika (Brown, 2012.).

Iako se opća pravila razlikuju od države do države, moguće je odrediti i neka njihova zajednička obilježja. Prvo, opće se pravilo može primijeniti samo ako porezni obveznik poduzimanjem određene transakcije (ili više njih), ostvaruje poreznu pogodnost (npr. porezno izuzeće), koju inače ne bi ostvario (Cooper, 200I.).

Drugo, primjena općeg pravila ovisi o svrsi ili cilju koji stoji iza transakcije. Opće se pravilo primjenjuje samo ako je svrha transakcije bila ostvarenje porezne pogodnosti, što navodi na zaključak da je svrha ključni element koncepta zakonitog izbjegavanja poreza (Cooper, 200I.). Iako se utvrđivanje svrhe, inherentno mentalnog elementa transakcije, može činiti složenim, iskustva većeg broja država ukazuju na moguće oslanjanje na određene objektivne elemente (npr. komercijalna supstanca transakcije) (Ernst \& Young, 20I3.). U tom smislu očiti se problem sastoji u razlikovanju "porezne svrhe" transakcije od druge poslovne (komercijalne) svrhe. Naime, iz perspektive poreznih obveznika, porezne pogodnosti pridonose povećanju ukupnog neto povrata, što promatranoj transakciji daje poslovno opravdanje (Cooper, 200I.). Sa stajališta nositelja porezne politike, kako je već navedeno supra, od ključne je važnosti označiti granicu između poreznog planiranja i izbjegavanja poreza, a kriterij svrhe transakcije čini se nepodobnim za ostvarenje ovog cilja (Atkinson, 2OI2.). Ovo se potvrđuje i u vidu tzv. poreznih izdataka, putem kojih država potiče poduzimanje određenih aktivnosti i kroz koje se ostvaruje regulatorna funkcija oporezivanja (Avi Yonah, 2006.). Zato je ključni korak u kvalifikaciji određene porezno motivirane aktivnosti kao izbjegavanja poreza utvrđivanje nesuglasja između njezinih rezultata, tj. ostvarene porezne pogodnosti, i cilja relevantnog poreznog pravila (Arnold, 2008.; Cooper, 200I.). Drugim riječima, konstitutivni element izbjegavanja poreza jest zloporaba (poreznog) prava (Ruiz Almendral, 2005.), što potvrđuju i opća pravila u mnogim državama (Arnold, 2008.). Dodatna teškoća u oslanjanju na svrhu transakcije kao uvjet za primjenu općeg pravila krije se u relativnoj važnosti drugih mogućih ciljeva transakcije. Iako ne postoji jedinstveno rješenje (Atkinson, 20I3.), postojanje značajne neporezne svrhe transakcije obično isključuje primjenu općeg pravila (Cooper, 200I.).

Ako su svi gore navedeni uvjeti za primjenu općeg pravila u odnosu na konkretnu transakciju ispunjeni, porezna tijela ovlaštena su uskratiti ili poništiti ostvarene porezne pogodnosti (Ernst \& Young, 2013.). Također, u brojnim državama porezna tijela imaju i pravo rekonstrukcije pravnog posla u skladu s 
utvrđenom ekonomskom stvarnošću te posljedičnog nametanja poreza na novoutvrđeni pravni posao (Prebble i Prebble, 20Io.). Iako prepuštanje tako širokih ovlasti poreznoj administraciji izaziva prijepore (Cooper, 200I.), to je ključan element svakog općeg pravila. U svakom slučaju, nositelji porezne politike moraju težiti da pomoću drugih obilježja općeg pravila daju poreznim tijelima dovoljno precizne smjernice za njegovu pravilnu primjenu. Jedno od porezno-tehničkih rješenja sastoji se i u ustanovljavanju posebnog savjetodavnog tijela, tzv. odbora za primjenu općeg pravila, čiji je zadatak štititi interese poreznog obveznika i davati savjete poreznim tijelima (Ernst \& Young, 20I3.).

\subsection{OPǴE PRAVILO I KONFLIKT RAZLIČITIH GILJEVA POREZNE POLITIKE: PROBLEM PRAVNE SIGURNOSTI}

Sa svim opisanim standardnim elementima koje sadrže, opća pravila prvenstveno služe kao mehanizam pojmovnog razgraničenja zakonitog izbjegavanja poreza. Povrh toga, ona omogućuju ukidanje poreznih pogodnosti koje porezni obveznici ostvaruju putem svojih transakcija koje su ex post, po inicijativi poreznih tijela i uz mogućnost sudskog nadzora, kvalificirane kao izbjegavanje poreza. Na taj način potiče se ostvarenje porezne pravednosti i učinkovitosti. Moguće učinke općeg pravila na ove ciljeve porezne politike valja razmatrati u smislu optimalne ravnoteže u primjeni općih načela i posebnih pravila u poreznom pravu (Weisbach, 2002.). U tom smislu opće se pravilo može označiti kao načelo koje umanjuje elastičnost oporezivog dohotka i uvećava učinkovitost poreznog sustava (Weisbach, 2002.). Također, kao posljedica povećane učinkovitosti redistribucija dohotka postaje jeftinija, što dovodi i do jače progresije poreznog sustava, tj. do njegove veće vertikalne pravednosti (Weisbach, 2002.).

U raspravama oko prednosti i nedostataka uvođenja općeg pravila u porezni sustav neke države, kritičari najčešće ističu njegov navodno negativni utjecaj na elemente pravne države, napose na načelo pravne sigurnosti. U suvremenim liberalnim demokracijama pravna je sigurnost ne samo jedan od glavnih elemenata pravne države, već i, u užem porezno-pravnom kontekstu, jedno od temeljnih načela oporezivanja, poznato već i u djelu Adama Smitha (Tooma, 2008.). U skladu s ovim načelom država pojedincima jamči mogućnost predviđanja pravnih implikacija vlastitog djelovanja i djelovanja drugih subjekata (Zolo, 2007.). Stoga njihovo ponašanje mora biti uređeno pravom, odnosno pravilima koja pružaju prikladne smjernice (Atkinson, 20I2.). U području oporezivanja, pravna sigurnost podrazumijeva sposobnost poreznih obveznika da unaprijed odrede porezne implikacije svojih aktivnosti (Atkinson, 2012.).

U tom smislu, standardni argument kritičara uvođenja općeg pravila sastoji se $u$ tome da ono podriva pravnu sigurnost, s obzirom da je nepodobno za crtanje jasne granice između zakonitog izbjegavanja poreza i poreznog planiranja (Prebble i Prebble, 20Io.). Kritičari ističu kako opće pravilo ne može pružiti prikladne smjernice poreznim obveznicima $\mathrm{u}$ vođenju njihovih poslova, dok $\mathrm{u}$ isto vrijeme poreznim tijelima prepušta široke diskrecijske ovlasti. S druge strane, Cooper (200I.) navodi kako je ova standardna kritika rijetko potkrijepljena čvrstim dokazima. Čak i ako se krene od navedene kritike kao pretpostavke, ostaje pitanje mogu li se bolji rezultati dobiti nekim alternativnim rješenjima za problem izbjegavanja poreza. Jedna od očitih alternativa je jače oslanjanje na posebna pravila, koja su puno preciznija. Posebna su pravila doista nužna za sprječavanje određenih poznatih tehnika izbjegavanja poreza (npr. transferne cijene), ali nisu održivo dugoročno rješenje (Cooper, 20oi.). Naime, poreznim obveznicima i njihovim savjetnicima puno je jednostavnije zaobići primjenu posebnog pravila u odnosu na primjenu općeg pravila. Pokušaji sprječavanja inovativnih tehnika izbjegavanja poreza donošenjem 
novih posebnih pravila stvaraju začarani krug kojim se samo povećava složenost poreznog sustava (Thurony, 2003.), što ujedno dovodi i do veće nesigurnosti (Freedman, 2004.). Nadalje, sama činjenica da se nositelji porezne politike opredjeljuju za usvajanje općeg pravila ukazuje na njihovu svijest o inherentnoj nepredvidivosti mogućih struktura poreznih obveznika (Prebble i Prebble, 20Io.).

Dva aspekta ukazuju na slabost kritike općeg pravila sa stajališta pravne sigurnosti. Prvo, pravna sigurnost nije ni primarni cilj niti evaluacijski kriterij općeg pravila (Freedman, 2004.). Ono teži ostvarenju drugih ciljeva porezne politike (npr. pravednost, učinkovitost, prikupljanje izgubljenih javnih prihoda), te stoga nužno mora biti neprecizno, bar u određenoj mjeri (Prebble i Prebble, 20Io.). Drugo, pravna sigurnost nije jedina vrijednost kojoj nositelji porezne politike moraju težiti te se nalazi u izravnom sukobu sa zahtjevima pravednosti i učinkovitosti (Zimmer, 2002.). Pravi se izazov porezne politike $\mathrm{u}$ tom smislu sastoji $\mathrm{u}$ pronalaženju odgovarajuće ravnoteže između tih suprotstavljenih ciljeva, pružajući dovoljne smjernice za ponašanje poreznih obveznika s jedne strane te učinkovit instrumentarij za suprotstavljanje izbjegavanju poreza s druge.

Konačno, valja dodati kako neki autori opovrgavaju standardnu tezu o negativnom utjecaju općeg pravila na načelo pravne sigurnosti. Polazna točka njihove analize je teorija Ronalda Dworkina (1978.) o dihotomiji između načela i pravila u pravu. U tom smislu Avery Jones (1996.) i Braithwhite (2002.) ističu potrebu za primjenom općenitijih načela umjesto specifičnijih pravila u zakonodavstvu kojim se sprječava izbjegavanje poreza. Načela su korisna u utvrđivanju značenja pravila, tj. $u$ tumačenju poreznog prava (Avery Jones, 1996.), a kombinacija načela, poput općeg pravila, i specifičnijih pravila pomaže stvaranju integriranog porezno-pravnog sustava, što pospješuje pravnu sigurnost (Braithwhite, 2002.). Freedman (2004.) je dalje razvila argument o ulozi općeg pravila kao općeg načela poreznog prava, s ciljem stvaranja smislenog regulatornog okvira u kojem se odlučuje o prihvatljivosti određenog ponašanja. Zanimljivo je kako je ova teza, koja potječe iz filozofije prava, pomirljiva s ekonomskom analizom učinaka općih načela i posebnih pravila, što je polazna točka Weisbachove (2002.) supra navedene analize učinkovitosti instrumenata namijenjenih sprječavanju izbjegavanja poreza.

\section{SPRJEČAVANJE IZBJEGAVANJA POREZA U DRŽAVAMA ǦLANIGAMA EU-A}

Vođenje porezne politike u državama članicama EU-a ima dodatnu dimenziju (Prebble i Prebble, 2008.), u obliku obveze poštivanja prava EU-a. Iako, uslijed ograničenja nadležnosti institucija EU-a u području oporezivanja, trenutno ne možemo govoriti ni o "EU porezima" niti o poreznoj politici Unije (Terra i Wattel, 20I2.), načelo nadređenosti prava EU-a nad pravnim sustavima pojedinih država članica ima značajne implikacije. Naime, nositelji porezne politike $u$ državama članicama suočavaju se $s$ ograničenjima koja proizlaze iz normi prava EU-a (Pistone, 2008.), što se posebno odražava i na pristup izbjegavanju poreza.

Komparativne analize mjera usmjerenih izbjegavanju poreza u državama članicama EU-a potvrđuju teze o jedinstvenosti odabranog pristupa u svakoj pojedinoj državi (Edgar, 2008.), što otežava stvaranje temeljnih odrednica ujednačenog EU pristupa (De Monès et al., 20Io.). S druge strane, pravo EU-a ima harmonizirajući učinak, postavljajući ograničenja a nacionalna pravila protiv izbjegavanja poreza moraju biti usklađena. Ta se ograničenja primjenjuju samo na one transakcije koje su pokrivene odredbama prava EU-a. Sud Europske Unije (CJEU), kao ovlašteni tumač prava EU-a, u većem je broju slučajeva odlučivao o usklađenosti nacionalnih pravila protiv izbjegavanja poreza s pravom EU-a, zbog čega se može govoriti o razvoju implicitnog koncepta izbjegavanja poreza primjenjivog u EU kontekstu (Weber, 2005.). 


\section{I. POJMOVNO ODREĐENJE IZBJEGAVANJA POREZA U PRAKSI SUDA EU-A}

Pristup CJEU-a u slučajevima koji su vezani uz izbjegavanje poreza temelji se na zabrani zloporabe prava, novopriznatom općem načelu prava EU-a. Sukladno tomu, porezni obveznici ne mogu računati na pogodnosti koje proizlaze iz prava EU-a ako svojim ponašanjem zlorabe primjenjive pravne norme. S obzirom da je CJEU veoma rano priznao da je porezno planiranje kojim se koriste pogodnosti unutarnjeg tržišta EU-a prihvatljivo (Schön, 2008.), bilo je potrebno odrediti granicu između slučajeva zloporaba, tj. izbjegavanja poreza, s jedne strane i legitimnog poreznog planiranja s druge. U tom smislu posebno su važne dvije poznate odluke CJEU-a.

Odluka u predmetu Halifax (CJEU, 2006a.) potvrđuje da se zloporaba sastoji od dva elementa, objektivnog i subjektivnog. Objektivni element zloporabe ispunjen je ako transakcije rezultiraju poreznim pogodnostima koje su suprotne cilju primjenjivih pravila prava EU-a. Subjektivni je element ispunjen ako je temeljni cilj transakcije bio ostvarenje porezne pogodnosti. S obzirom da se u predmetu Halifax razmatrala zloporaba odredbi EU Direktive o zajedničkom sustavu poreza na dodanu vrijednost, bilo je upitno može li se isti ili sličan test primijeniti i na druga, neharmonizirana područja, poput izravnih poreza. U tom je smislu od ključne važnosti odluka u predmetu Cadbury Schweppes (CJEU 2006b.), u kojem se razmatrala usklađenost nacionalnih pravila protiv izbjegavanja poreza - preciznije, pravila protiv kontroliranih inozemnih korporacija (tzv. CFC pravila) - sa slobodom poslovnog nastana. CJEU je odlučio kako izbjegavanje poreza opravdava ograničenje tržišnih sloboda samo u slučajevima tzv. "potpuno umjetnih konstrukcija" (engl. wholly artificial arrangements). Iako je razvoj ove utjecajne doktrine u praksi CJEU-a započeo već 1998. godine u predmetu ICI (Schön, 20I3.), tek je nakon odluke u predmetu Cadbury Schweppes postalo jasno kako se "potpuno umjetne konstrukcije" identificiraju primjenom dvostrukog testa (Lampreave, 20I2.), koji je veoma sličan onome opisanom u odluci u predmetu Halifax. Subjektivni element testa podrazumijeva analizu cilja (svrhe) transakcije poreznog obveznika, gdje se posebno ističe traganje za valjanom poslovnom, neporeznom svrhom transakcije. Objektivni element testa uključuje analizu ekonomske stvarnosti konstrukcije poreznog obveznika u njezinoj ukupnosti, gdje manjak ekonomske supstance upućuje na umjetnost konstrukcije.

Čini se da je u budućoj praksi CJEU-a potvrđeno stajalište kako su odluke u predmetima Halifax i Cadbury Schweppes utemeljene na jedinstvenoj teoriji o zabrani zloporabe (Jimenez, 20I2.). Posebno je značajno ukazati kako pristup CJEU-a u predmetima koji se tiču izbjegavanja poreza dijeli obilježja veoma slična glavnim elementima općih pravila koja nalazimo u zakonodavstvu većeg broja država (vidi: supra, poglavlje 2.2.). Naime, ključni kriteriji koje CJEU primjenjuje pri razgraničavanju koncepta izbjegavanja poreza jesu: (I) cilj pravila prava EU-a na koja se oslanja subjekt u pitanju (objektivni element); (2) namjera subjekta da ostvari porezne pogodnosti zloporabom primjenjivog pravila (subjektivni element); te (3) relativna važnost "porezne svrhe" transakcije u odnosu na druge, "neporezne", komercijalne ciljeve. Sukladno tomu, moguće je tvrditi kako je CJEU razvio opće pravilo protivi izbjegavanja poreza primjenjivo u EU kontekstu (Sinfield, 2OII.). Iako se u praksi CJEU-a još nije pojavilo pitanje usklađenosti općih pravila pojedinih država članica s "EU općim pravilom", bogata sudska praksa koja se tiče različitih posebnih pravila protiv izbjegavanja pravila potvrđuje zaključak da unutarnja pravila protiv izbjegavanja poreza moraju poštivati ograničenja postavljena u pravu EU-a (Ruiz Almendral, 20I3.). Takva, tzv. negativna integracija poreznih sustava država članica ${ }^{5}$ izaziva prijepore, s obzirom da CJEU nije institucija nadležna za vođenje porezne politike (Dahlberg, 2007.).

\footnotetext{
${ }^{5} \mathrm{O}$ dihotomiji između pozitivne i negativne integracije poreznih sustava država članica vidjeti Terra i Wattel (20I2.).
} 


\subsection{PUT KA JEDINSTVENOM OPĆEM PRAVILU PROTIV IZBJEGAVANJA POREZA U EU: PREPORUKA EUROPSKE KOMISIJE O AGRESIVNOM POREZNOM PLANIRANJU}

U prosincu 20I2. godine Europska je komisija donijela Preporuku o agresivnom poreznom planiranju, neobvezujući akt upućen državama članicama kojim se postavlja okvir harmoniziranog EU pristupa najagresivnijim oblicima izbjegavanja poreza. Jedna od njegovih najambicioznijih točki prijedlog je za usvajanjem uniformnog općeg pravila protiv izbjegavanja poreza u svim državama članicama. Pravilo valja primjenjivati jednako na sve transakcije, bez obzira poduzimaju li se isključivo u unutarnacionalnom kontekstu ili sadrže prekogranični element (Lyons, 2013.). Izričaj predloženog pravila temelji se na praksi CJEU-a, napose na doktrini "potpuno umjetnih konstrukcija", definiranih u predmetu Cadbury Schweppes. Naime, primjena predloženog općeg pravila ograničena je samo na umjetne konstrukcije (tj. konstrukcije bez komercijalnog sadržaja), koje se poduzimaju s glavnim ciljem izbjegavanja poreza te rezultiraju ostvarenjem poreznih pogodnosti (EK, 20I2.). Preporuka sadrži i primjeričnu listu konstrukcija bez komercijalnog sadržaja te definira ostale pojmove iz općeg pravila; preciznije, definirani su pojmovi: "konstrukcija", "glavni cilj izbjegavanja poreza" te "porezna pogodnost". Ako su svi uvjeti za primjenu predloženog općeg pravila ispunjeni, porezna tijela moraju tretirati umjetne konstrukcije u skladu s njihovim ekonomskim sadržajem, tj. imaju ovlast rekarakterizacije.

Čini se da je EK svjesna nedostataka negativne integracije u području izbjegavanja poreza. Pravna sigurnost i konkurentnost na unutarnjem tržištu mogu se istinski ostvariti samo pozitivnom integracijom, tj. normativnim reguliranjem harmoniziranih pravila s EU razine (Sinfield, 2OII.). U tom smislu najveća je prepreka manjak ovlaštenja institucija EU-a u reguliranju područja oporezivanja. S druge strane, mehanizmi tzv. "soft law-a", poput gore navedene preporuke EK-a, mogli bi ostvariti veći uspjeh u promijenjenom ekonomskom okruženju. Velika recesija i dužnička kriza država članica EU-a koja je uslijedila ukazuju da mane poreznih sustava država članica mogu postati problem i na široj, EU razini. Države članice koje su zatražile financijsku pomoć EU-a susrele su se sa zahtjevima vezanim uz unaprjeđenje razine ispunjavanja poreznih obveza, uključujući i ozbiljniji pristup problemima izbjegavanja poreza (Lyons, 20I3.). Ovo potvrđuju i porezne reforme u državi koja simbolizira krizu eurozone - Grčkoj. Tijekom 2013. godine, između ostalih mjera poduzetih s ciljem borbe protiv neispunjavanja poreznih obveza, u Grčkoj je po prvi put uvedeno opće pravilo (Stathis, 20I4.). Izričaj ovog pravila - koje se primjenjuje od I. siječnja 20I4. godine - uvelike slijedi izričaj uniformnog EU općeg pravila predloženog od strane EK-a, s obzirom da je glavni uvjet za njegovu primjenu utvrđenje umjetnih konstrukcija.

\subsection{PREgLed OPǴIH PRAVILA U IZABRANIM DRŽAVAMA ǦLANIGAMA EU-A POGOĐENIH EKONOMSKOM KRIZOM}

Veći broj država članica EU-a odlučio se za uvođenje općeg pravila, kao instrumenta protiv izbjegavanja poreza, puno prije nego je u praksi CJEU-a razvijeno implicitno "EU opće pravilo". Neke su od tih država u međuvremenu snažno pogođene posljedicama ekonomske krize, što je dovelo i do preispitivanja porezne politike. Prikaz različitih općih pravila uvedenih u Španjolskoj, Italiji i Portugalu može biti od koristi i za nositelje porezne politike u Hrvatskoj, najnovijoj državi članici EU-a, koja se u isto vrijeme odlikuje sličnom pravnom tradicijom i usporedivim razinama onih čimbenika koji utječu na ispunjavanje poreznih obveza (npr. porezni moral) (McGee i Tyler, 2006.). Sve tri navedene države uvele su opće pravilo u vlastite porezne sustave puno prije izbijanja krize 2008. godine, s ciljem postizanja pravedne raspodjele poreznog tereta i povećanja razine prikupljenih poreznih prihoda. Dok je u Italiji 
opće pravilo razvijeno u sudskoj praksi, u Španjolskoj i Portugalu postoji zakonsko opće pravilo. Pritom se primjećuje znatan utjecaj prava EU-a te napose prakse CJEU-a, u sve tri države. Naime, usklađenost mnogih elemenata njihovih poreznih sustava s pravom EU-a, čak i u neharmoniziranim područjima poput izravnih poreza, bila je predmetom sudske kontrole (Ruiz Almendral, 2005.).

Španjolski porezni sustav sadrži opće pravilo protiv izbjegavanja poreza, kao i više različitih posebnih pravila (Clifford Chance, 2013.). Opće je pravilo prvi put uvedeno 1963. godine, ali se vrlo rijetko primjenjivalo od strane poreznih tijela. Novi španjolski Opći porezni zakon iz 2003. godine uveo je potpuno novo opće pravilo koje jasnije definira izbjegavanje poreza, s ciljem revitalizacije njegove uporabe od strane poreznih tijela i sudova (Ruiz Almendral, 2005.). Zakonito izbjegavanje poreza, koje se označuje pojmom "sukob u primjeni poreznih pravila", obuhvaća dvije skupine slučajeva (Soler Roch, 2004.): (I) slučajevi kod kojih porezni obveznik izbjegava oporezivi događaj ili umanjuje poreznu osnovicu putem transakcije koja je umjetna ili netipična za postizanje ostvarenog rezultata, te (2) transakcije koji dovode do materijalno-pravnih ili gospodarskih učinaka ili pogodnosti koje odudaraju od onih koji bi bili ostvareni transakcijama koje nisu umjetne.

Primjena općeg pravila zahtijeva od španjolskih poreznih tijela dokazivanje zloporabe prava. To uključuje analizu ponašanja poreznog obveznika, čiji je cilj utvrditi jesu li njegovi pravni poslovi i/ili transakcije umjetni ili ne. Španjolski Opći porezni zakon sadrži dodatni upravno-pravni uvjet za primjenu općeg pravila. Radi se o posebnom izvješću o poreznoj zloporabi, koje je obvezujuće za porezno tijelo (De Monès et al., 20Io.). To izvješće donosi posebni savjetodavni odbor u čijem su sastavu po dva predstavnika savezne vlasti i po dva predstavnika nadležnog poreznog tijela. Poreznom se obvezniku ostavlja I5 dana da izloži svoj slučaj pred odborom, koji zatim donosi izvješće (Tooma, 2008.). Posljedica primjene općeg pravila je poništavanje ostvarenih poreznih pogodnosti te nametanje kamate na zakašnjelo plaćanje poreznog duga. Čini se kako su upravo uslijed navedenih postupovno-pravnih zahtjeva dokazivanja zloporabe, nužnih za primjenu općeg pravila, porezna tijela i sudovi u Španjolskoj skloniji širokom tumačenju poreznog prava. Također, iz perspektive nositelja porezne politike, posljednji trendovi ukazuju na sve veće oslanjanje na detaljna posebna pravila, umjesto na širenje primjene općeg pravila (Clifford Chance, 2013.).

U talijanskom poreznom pravu, uz mnogobrojna posebna pravila protiv izbjegavanja poreza, nalazimo i opće pravilo. Temeljem članka 37bis Dekreta predsjednika Republike br. 600/1973, usvojenog 1997. godine, porezna tijela ovlaštena su zanemariti transakcije čiji je cilj ostvarenje poreznih pogodnosti, a nedostaje im valjana komercijalna svrha (De Monès et al., 20IO.). Iako se ovo pravilo široko primjenjuje, ne radi se o općem pravilu protiv izbjegavanja poreza u užem smislu. Naime, njegova je primjena izričito ograničena na taksativno navedene transakcije, što ga približava pojmu posebnog pravila. S druge strane, u praksi talijanskih sudova tijekom godina potvrđeno je stajalište kako je opće pravilo protiv izbjegavanja poreza doista element talijanskog poreznog sustava. Fleksibilan pristup sudova u slučajevima izbjegavanja poreza, koji odobrava poreznim tijelima zanemarivanje čitavog niza poreznih pogodnosti, posebno je naglašen nakon 2005. godine. Ključna je pritom uloga talijanskog Vrhovnog suda, koji je potvrdio da odsutnost izričitog zakonskog pravila protiv izbjegavanja poreza ne sprječava porezna tijela i sudove da ponište transakcije poreznih obveznika te nametnu poreznu obvezu, i to s obzirom na primjenu građansko-pravne doktrine zabrane zloporabe prava (Cordeiro Guerra i Mastellone, 2009.). Vrhovni je sud u obranu ovakvog pristupa, koji de facto znači razvoj sudskog općeg pravila, iznio niz argumenata, uključujući i načelo plaćanja poreza sukladno gospodarskoj snazi (engl. 
ability to pay principle), sadržanom u čl. 53. talijanskog Ustava (Garbarino, 2012.), ali i načelo zabrane zloporabe prava, razvijeno u praksi CJEU-a (Soler Roch, 2OI2.).

Ovakav razvoj za posljedicu je imao da su talijanska porezna tijela sada puno otvorenija za primjenu pravila sadržanog u čl. 37bis Dekreta br. 600/1973 ili za pozivanje na opće načelo zabrane zloporabe prava pri suprotstavljanju izbjegavanju poreza (Ernst \& Young, 20I3.). Transakcija se kvalificira kao zloporaba ako je njezin glavni cilj ostvarenje porezne pogodnosti te nema jasnog ekonomskog razloga za njezino poduzimanje. Teret dokazivanja, i porezne pogodnosti i elemenata koji ukazuju na zloporabu, na poreznim je vlastima. S druge strane, porezni obveznici mogu opravdati transakciju ukazivanjem na jasne i značajne poslovne razloge njezina poduzimanja. U slučajevima rekarakterizacije transakcije od strane poreznih vlasti, porezni će obveznik dugovati onaj iznos poreza koji bi bio dužan platiti kao da nije poduzeo osporenu transakciju. Prema stajalištu Vrhovnog suda, na osporene transakcije ne smiju se primijeniti niti novčane kazne niti kazneno-pravne sankcije (Clifford Chance, 20I3.).

Portugalsko opće pravilo određuje da je svaka transakcija poduzeta na umjetni ili prijevarni način ili zloporabom pravnih formi te s jedinim ili glavnim ciljem ostvarenja poreznih pogodnosti nevažeća za potrebe poreznog prava. Porezna obveza bit će nametnuta u skladu s pravilima koja bi bila primjenjiva $u$ slučaju da transakcija nije poduzeta te se namjeravane ili ostvarene porezne pogodnosti neće priznati (Santiago, Salema i Carvalho Nunes, 20II.). Ovakvo je pravilo dio portugalskog poreznog sustava od I999. godine te postoji zajedno s više posebnih pravila (npr. ono o potkapitalizaciji). Cilj je tih pravila osigurati poštivanje načela jednakosti u financiranju javnih rashoda. Zbog teškoća u primjeni općeg pravila, napose zbog tereta dokazivanja koji pada na porezna tijela, veću su važnost u praksi imala posebna pravila te se opće pravilo nije primjenjivalo gotovo cijelo desetljeće od njegova uvođenja (Fernandes Ferreira et al., 2OII.). Ipak, posljednje razdoblje obilježava trend pojačane primjene općeg pravila.

\section{PRISTUP ZAKONITOM IZBJEGAVANJU POREZA U HRVATSKOJ}

Tijekom 199o-ih godina kao razdoblja tranzicije u Hrvatskoj bilo je potrebno stvoriti novi porezni sustav, usklađen s osnovnim postavkama tržišne ekonomije (Arbutina et al., 20I4.). Stoga ne iznenađuje kako je utaja poreza prepoznata kao važnije pitanje porezne politike od zakonitog izbjegavanja poreza. U narednom razdoblju više je zakonodavnih intervencija bilo usmjereno sprječavanju poznatih struktura izbjegavanja poreza. Potreba za uporabom zakonodavnih instrumenata $\mathrm{u}$ borbi protiv izbjegavanja poreza u Hrvatskoj izravna je posljedica temeljnih obilježja hrvatskog pravnog sustava. Uz pripadnost kontinentalnom pravnom krugu i važnost ustavnog načela zakonitosti hrvatski pravni sustav odlikuje i duga tradicija gramatičkog tumačenja prava od strane sudova (Aviani i Đerđa, 20I2.). Stoga pregled dinamike zakonodavnih promjena u ovom području otkriva kako Hrvatskoj nedostaje koherentni pristup zakonitom izbjegavanju poreza (Prebble, 2005.). U usporedbi s drugim državama, hrvatski je pristup ovom važnom pitanju porezne politike $u$ isto vrijeme i nerazvijen i fragmentiran.

\section{I. ZAKONSKI OKVIR ZA SPRJEČAVANJE IZBJEGAVANJA POREZA DE LEGE LATA}

Kao i u mnogim drugim državama obveza plaćanja poreza u Hrvatskoj opravdava se ustavnim načelom sposobnosti za plaćanja. Čl. 5I. Ustava RH propisuje da je "svatko dužan sudjelovati u podmirenju javnih troškova, u skladu sa svojim gospodarskim mogućnostima", te da se "porezni sustav temelji na načelima jednakosti i pravednosti". Ova temeljna ustavna načela ujedno predstavljaju i ciljeve kojima moraju težiti nositelji porezne politike u Hrvatskoj te se odražavaju u nizu zakonskih odredbi. Primjerice, čl. 9. hrvatskog Općeg poreznog zakona (OPZ) obvezuje sudionike porezno-pravnog odnosa na postupanje u 
dobroj vjeri, tj. na savjesno i pošteno postupanje u skladu sa zakonom. Izbjegavanje poreza suprotno je ustavnom načelu pravednosti jer onemogućuje ostvarenje i horizontalne i vertikalne dimenzije pravednosti u oporezivanju. Sukladno tomu, donošenje zakonskih instrumenata s ciljem sprječavanja izbjegavanja poreza u Hrvatskoj, uključujući i opće pravilo, može se opravdati ovim ustavnim načelom, što potvrđuje i razvoj sudskog pristupa izbjegavanju poreza u Italiji (vidi supra, poglavlje 3.3.).

U hrvatskom poreznom zakonodavstvu ne nalazimo opće pravilo protiv izbjegavanja poreza (Rogić Lugarić i Bogovac, 20I2.). Međutim, postoje određene odredbe kojima je moguće ostvariti slične ciljeve. Od posebnog je značaja odredba iz čl. Io., st. I. OPZ-a, koja propisuje tzv. gospodarski pristup u postupku utvrđivanja porezne obveze, odnosno kojom se kodificira načelo prevage sadržaja u odnosu na formu. Prema toj odredbi "porezne se činjenice utvrđuju prema njihovoj gospodarskoj biti". Dodatno, čl. Io., st. 2. OPZ-a određuje: "(A)ko je prihod, dohodak, dobit ili druga procjenjiva korist ostvarena bez pravne osnove, porezno tijelo utvrdit će poreznu obvezu u skladu s posebnim zakonom kojim se uređuje pojedina vrsta poreza." Načelo gospodarskog pristupa omogućuje poreznim tijelima da oporezuju dobit ostvarenu kaznenim djelom, s obzirom da se porez nameće na ekonomsku supstancu, a priroda pravnog posla koji je doveo do ostvarenja dobiti nije bitna za porezno pravo (Rogić Lugarić i Bogovac, 20I2.). Sukladno tomu, načelo gospodarskog pristupa može se smatrati i potencijalno moćnim alatom usmjerenim protiv izbjegavanja poreza, usporedivim s općim pravilom (KPMG, 20I3.). Međutim, odredbe OPZ-a o gospodarskom pristupu nedovoljno su precizne i ne pružaju detaljnije upute za njihovu primjenu poreznim tijelima. Stoga nije iznenađujuće da - unatoč tomu što su ove odredbe u nepromijenjenom obliku na snazi još od 200I. godine - njihova uloga pri sprječavanju izbjegavanje poreza nije prepoznata od strane poreznih tijela.

Čl. II. OPZ-a predstavlja kodifikaciju građanskopravne doktrine simulacije, usmjerenu sprječavanju zloporabe pravne forme: "(A)ko se prividnim pravnim poslom prikriva neki drugi pravni posao, tada je osnova za utvrđivanje porezne obveze prikriveni pravni posao". Na temelju ove odredbe porezna tijela imaju ovlast rekarakterizacije transakcije u pitanju, zanemarujući pravni oblik odabran od strane stranaka transakcije. Sukladno tomu, smatrat će se da je pravni posao sklopljen u onom obliku koji odgovara stvarnim namjerama stranaka (Šimović et al, 20Io.). Iako se ova odredba rijetko primjenjuje u praksi, neki su autori mišljenja da će imati sve veću važnost u narednom razdoblju, napose kad se radi o kupoprodaji nekretnina (Kapetanović, 20IO.; Prebble i Prebble, 2008.).

Hrvatsko porezno pravo sadrži i više posebnih pravila protiv izbjegavanja poreza, uglavnom u području oporezivanja dobiti trgovačkih društava. Tako primjerice Zakon o porezu na dobit (ZPDob) sadrži pravilo o potkapitalizaciji te pravilo o primjeni povećane stope poreza na odbitku na određene naknade koje hrvatskih rezidenti isplaćuju rezidentima poreznih utočišta, država izričito navedenih u posebnom popisu objavljenom od strane Ministarstva financija. Posebno je zanimljivo uočiti kako i neke od recentnih izmjena poreznog zakonodavstva - uključujući i usvajanje novih posebnih pravila - očito odražavaju svijest o potrebi sprječavanja izbjegavanja poreza. S druge strane, ne može se jasno odrediti na kojim se zajedničkim teorijskim postavkama ovaj zakonodavni pristup temelji.

Izmjene OPZ-a iz 20I2. godine, kojim je uveden poseban postupak "proboja pravne osobnosti" trgovačkih društava u poreznim stvarima, zakonodavac je opravdao načelom zabrane zloporabe prava, jednim od temeljnih načela hrvatskog građanskog prava (Žunić Kovačević i Gadžo, 2013.). Ova je novela izazvala snažne reakcije poslovne zajednice, s obzirom da članovi društava, članovi uprave i izvršni direktori društava, kao i povezane osobe, mogu postati odgovorni za porezni dug društava, ako porezna tijela utvrde da je nemogućnost plaćanja poreznog duga prouzrokovana zloporabom prava ili ovlasti od 
strane tih osoba. Posebno pravilo protiv izbjegavanja poreza uvedeno je i novelom ZPDob-a iz 2012. godine, kojom je uvedena tzv. olakšica za reinvestiranu dobit. Temeljem ove olakšice, osnovica poreza na dobit može se umanjiti za iznos povećanja temeljnog kapitala društva učinjenog u svrhu investiranja i razvoja. Zakonodavac je, s ciljem sprječavanja zloporabe ove porezne olakšice, uveo posebno pravilo koje određuje da se ona neće priznati ako je razvidno da je povećanje temeljnog kapitala društva izvršeno s ciljem utaje poreza ili izbjegavanja plaćanja poreza (Jozipović, 2013.). Potreba za utvrđivanjem cilja akcije koju poduzima porezni obveznik ono je po čemu je navedeno posebno pravilo slično općim pravilima protiv izbjegavanja poreza koja nalazimo u poreznim sustavima drugih država.

Također, izričaj navedenog posebnog pravila može se usporediti s pravilima sadržanim u tri direktive EU-a iz područja izravnih poreza. Odredbe Direktive o spajanjima (Vijeće EU-a, I990a.), Direktive o matičnom i zavisnom društvu (Vijeće EU-a, 199ob.) i Direktive o isplatama kamata i autorskih naknada između povezanih društava (Vijeće EU-a, 2003.) implementirane su u hrvatsko zakonodavstvo tijekom postupka pristupanja Hrvatske EU. Čini se da se hrvatski zakonodavac opredijelio za uniformni pristup protiv izbjegavanja poreza vezanog za pogodnosti iz navedenih direktiva. Naime, pogodnosti iz direktiva neće se priznati ako je glavni ili jedan od glavnih ciljeva transakcije/konstrukcije u pitanju utaja poreza ili izbjegavanje poreza. Moguće je zaključiti kako je harmonizacija hrvatskog poreznog prava s pravom EU-a dovela do značajnih promjena u pristupu zakonodavca izbjegavanju poreza, što je važno saznanje za vođenje porezne politike u budućnosti. Najvažnija se promjena tiče izričitog priznavanja subjektivnog elementa, namjere poreznog obveznika pri poduzimanju promatrane transakcije, kao konstitutivnog elementa zakonitog izbjegavanja poreza, iako tek u ograničenom broju posebnih pravila.

\subsection{PRIJEDLOG ZA UVOĐENJEM OPĆEg PRAVILA U HRVATSKO POREZNO PRAVO: NAČELO PRAVNE SIGURNOSTI KAO POLAZNA TOČKA}

Iz pregleda hrvatskog zakonodavstva u ovom području moguće je zaključiti kako su nositelji porezne politike mjeru uvođenja općeg pravila u hrvatski porezni sustav ocijenili nepotrebnom te su posebna pravila prepoznata kao oslonac borbe protiv zakonitog izbjegavanja poreza. Detaljnija analiza dinamike zakonodavnih promjena upućuje da bi takav zaključak bio pogrešan jer hrvatski pristup ovom problemu nije koherentan. Posebno je zabrinjavajući nedostatak uniformnih kriterija koji se moraju primjenjivati pri razgraničenju koncepta izbjegavanja poreza (vidi supra, poglavlje 2.2.). Kako je u radu navedeno, u nekim slučajevima (npr. u primjeni odredbi OPZ-a o prividnim poslovima ili o "proboju pravne osobnosti trgovačkih društava"), razlikovno obilježje izbjegavanja poreza jest postojanje zloporabe prava. U tim slučajevima cilj, porezni ili ne-porezni, koji je porezni obveznik želio postići poduzimanjem kakvog pravnog posla, nije bitan. U drugim slučajevima (npr. pri primjeni posebnog pravila o sprječavanju izbjegavanja poreza korištenjem olakšice za reinvestiranu dobit ili korištenjem pogodnosti iz EU direktiva iz područja izravnih poreza), upravo je cilj koji porezni obveznik želi postići ključni element prema kojem se procjenjuje radi li se o izbjegavanju poreza ili ne.

Kako je u radu navedeno (vidi supra, poglavlje 3.I.), u praksi CJEU-a potvrđena je važnost i objektivnog kriterija (zloporabe primjenjivih pravnih pravila) i subjektivnog kriterija (cilja transakcije koju poduzima porezni obveznik) kao konstitutivnih elemenata izbjegavanja poreza. Sukladno tomu, u svjetlu zahtjeva prava EU-a moguće je pomiriti divergentne kriterija koje hrvatsko pravo poznaje pri pojmovnom određenju izbjegavanja poreza. Pogotovo ako se ima u vidu da su hrvatska porezna tijela i sudovi obvezna držati se koncepta izbjegavanja poreza razvijenog u praksi CJEU-a kad god primjenjuju nacionalna pravila na prekogranične transakcije na koje se primjenjuje pravo EU-a. 
U tom smislu slabosti preciznog i dosljednog zakonodavnog definiranja onog ponašanja poreznih obveznika koje valja smatrati izbjegavanjem poreza mogu imati ozbiljne posljedice. Primjerice, nejasno je na koji će način hrvatska porezna tijela utvrđivati subjektivni element (cilj transakcije) pri (ne)priznavanju olakšice za reinvestiranu dobit. Preciznije upute o tomu ne nalazimo niti u zakonskim i podzakonskim aktima niti u (neobvezujućim) mišljenjima Porezne uprave. Nadalje, značaj načela zabrane zloporabe prava $\mathrm{u}$ daljnjem razvoju hrvatskog poreznog prava ostaje nejasan. Postavlja se pitanje hoće li se zakonodavac i u budućnosti pozivati na ovo načelo pri uvođenju novih posebnih pravila protiv izbjegavanja poreza, po uzoru na odredbe o "proboju pravne osobnosti trgovačkih društava". Pritom posebno valja naglasiti kako je o ovom i o sličnim pitanjima izostao argumentirani dijalog i rasprava između svih zainteresiranih strana. Stoga ne čudi kako porezni obveznici u Hrvatskoj ne mogu unaprijed utvrditi porezno-pravne implikacije svojih aktivnosti, što implicira neostvarenje načela pravne sigurnosti (vidi supra, poglavlje 2.3.). Nalazi jedne novije studije, koji upućuju da je u poslovnim krugovima razina pravne (ne)sigurnosti u poreznim stvarima prepoznata kao jedna od glavnih prepreka stranim ulaganjima (Rogić Lugarić i Bogovac, 20I2.), potvrđuju ovaj zaključak.

Mišljenja smo da je hrvatski porezni sustav idealan primjer na koji način uvođenje općeg pravila protiv izbjegavanja poreza ustvari može pomoći ostvarenju pravne sigurnosti, suprotno standardnim prigovorima kritičara ovog instrumenta. Opći problem hrvatskog poreznog sustava sve od njegove sveobuhvatne reforme iz I994. godine jest nestabilnost zakonodavnog okvira (Bejaković, 2009.; Žunić Kovačević, 2OI2.), što se odražava i u području borbe protiv izbjegavanja poreza, u kojem je naglasak bio na usvajanju sve većeg broja posebnih pravila. Izostanak zadovoljavajućeg pojmovnog određenja izbjegavanja poreza, ni u zakonskim odredbama niti u sudskoj praksi, za neizbježnu je posljedicu imao ugrožavanje pravne sigurnosti. Tu prazninu može popuniti opće pravilo protiv izbjegavanja poreza koje, unatoč svojoj inherentnoj nepreciznosti, ima potencijal pružanja adekvatnih smjernica za primjenu poreznog prava poreznim tijelima i sudovima, poštujući opće ciljeve porezne politike. Analiza posljedica uvođenja izmijenjenog općeg pravila u Španjolskoj (Ruiz Almendral, 2005.), državi s usporedivom pravnom tradicijom i sličnim stavom sudova prema tumačenju poreznog prava, potvrđuje izneseni stav.

Pritom se ne smije zanemariti kako su za ocjenu mogućeg utjecaja uvođenja općeg pravila na pravnu sigurnost od ključne važnosti njegova porezno-tehnička obilježja. U tom smislu mišljenja smo da hrvatsko opće pravilo mora slijediti izričaj pravila predloženog u preporuci Europske komisije iz 2012. godine (vidi supra, poglavlje 3.2.). Kako je u radu već navedeno, neke odredbe hrvatskog poreznog prava usmjerene sprječavanju izbjegavanja poreza imaju određena zajednička obilježja s predloženim "EU općim pravilom". U kontekstu načela pravne sigurnosti osnovna je prednost uvođenja takvog pravila da njegov izričaj, koji je usklađen s praksom CJEU-a, pruža veoma detaljne smjernice za klasifikaciju određenog ponašanja kao izbjegavanja poreza, i poreznim tijelima i sudovima i samim poreznim obveznicima. Pritom sam CJEU može imati važnu ulogu pri razjašnjenju neizbježnih nedoumica $u$ budućoj praksi primjene ovakvog pravila (Clifford Chance, 2013.). Također, pravna se sigurnost može pospješiti uvođenjem određenih instituta uz opće pravilo. Posebno upozoravamo na potrebu uspostave posebnog odbora za primjenu općeg pravila (za španjolski model vidi supra, poglavlje 3.3.) te potrebu uvođenja instituta obvezujuće informacije koju porezni obveznici mogu zatražiti od poreznih tijela (Žunić Kovačević, 2013.).

Uvođenje općeg pravila modeliranog u skladu s preporukom EK-a u hrvatski porezni sustav ne znači ujedno i zanemarivanje uloge posebnih pravila, usmjerenih sprječavanju specifičnih tehnika 
izbjegavanja poreza. U skladu s doktrinom lex specialis derogat legi generali takva posebna pravila moraju imati prednost u primjeni u odnosu na opće pravilo, što također pospješuje pravnu sigurnost. Još jedan instrument čiju primjenu valja razmotriti u budućoj normativnoj praksi jest uvođenje obveze poreznih obveznika da poreznim tijelima objave uporabu određenih poznatih tehnika poreznog planiranja. Ovaj se institut pokazao učinkovitim u nekim državama, poput SAD-a (Kaye, 20I2.).

\subsection{MOGUĆNOSTI OSTVARENJA DRUGIH GILJEVA POREZNE POLITIKE UVOĐENJEM OPǴEG PRAVILA}

Ostvarenje načela pravne sigurnosti nije jedini cilj porezne politike (vidi supra, poglavlje 2.3.). U analizi potrebe uvođenja općeg pravila u porezni sustav neke države mora se uzeti u obzir i njegov utjecaj na druge ciljeve. U Hrvatskoj posebno mjesto ima ustavno načelo porezne pravednosti. S obzirom da izbjegavanje poreza ugrožava ostvarenje ovog, ali i drugih ciljeva oporezivanja (npr. učinkovitost), stvaranje koherentnog pristupa sprječavanju izbjegavanja poreza ne smije biti zanemareno od strane nositelja porezne politike.

Ono što može predstavljati svojevrsnu kočnicu za nužne reforme u ovom području nedostatak je empirijskih dokaza o stvarnom opsegu zakonitog izbjegavanja poreza u Hrvatskoj. S druge strane, određena saznanja moguće je dobiti posredno, analizom čimbenika koji se u teoriji obično navode kao indikatori izbjegavanja poreza (International Tax Compact, 20Io.). Ovi indikatori, kao što su razina poreznog morala, veličina sive ekonomije, razina korupcije, frekvencija promjene poreznog zakonodavstva i dr., upućuju da u Hrvatskoj doista postoji relativno visoka razina izbjegavanja poreza. Također treba uzeti u obzir i da porezni izdaci, čija je primjena raširena u Hrvatskoj, po samoj svojoj prirodi otvaraju prilike za (zakonito) izbjegavanje poreza (Tyson, 20I4.). Čini se kako su i nositelji porezne politike barem donekle svjesni ovog problema, na što ukazuju neke od posljednjih izmjena poreznog zakonodavstva (npr. uvođenje posebnog pravila protiv izbjegavanja poreza pomoću olakšice za reinvestiranu dobit). Paralelno je uočljiva i primjena drugih instrumenata usmjerenih povećanju razine ispunjavanja poreznih obveza te umanjenju poreznog jaza (npr. osnivanje posebne ustrojstvene jedinice Porezne uprave za velike porezne obveznike, objava liste poreznih dužnika i dr.). S druge strane, upitno je koliko su ove i druge mjere porezne politike bile motivirane ciljevima pravednosti i učinkovitosti, a koliko nekim drugim, prizemnijim ciljevima.

Naime, valja imati u vidu da su promjene u hrvatskom poreznom sustavu sve od izbijanja posljednje recesije (koja nažalost još uvijek traje), uglavnom motivirane potrebom za provođenjem fiskalne konsolidacije (Arbutina et al., 20I4.). Također, hrvatske se javne financije trenutno nalaze u postupku nadzora od strane institucija EU-a, s obzirom da je veoma brzo po pristupanju Uniji postalo jasno da država ne može zadovoljiti fiskalno pravilo vezano uz razinu dopuštenog proračunskog deficita. Dok se najveći dio akademske i stručne javnosti slaže kako prostora za daljnje povećanje poreznog opterećenja nema, napose uzevši u obzir visoko opterećenje rada i potrošnje, mogući fiskalni učinci poboljšanja razine ispunjavanja poreznih obveza u većoj su mjeri zanemareni. Iskustva drugih država članica EU-a teško pogođenih krizom (npr. Grčka, Irska, Portugal, Cipar) pokazuju da je jedan od uvjeta za dobivanje financijske pomoći od institucija EU-a i sistemski pristup eliminiranju strukturnih nedostataka nacionalnog poreznog sustava, što uključuje i ispunjavanje poreznih obveza (Lyons, 2013.). U tom smislu, poboljšanje pristupa sprječavanju izbjegavanja poreza ujedno znači i slanje signala institucijama EU-a i financijskim tržištima da Hrvatska vodi fiskalno odgovornu politiku. 
Uvođenjem općeg pravila protiv izbjegavanja poreza u hrvatski porezni sustav, u skladu s preporukom EK-a iz 2012. godine, moguće je ostvariti sve gore navedene ciljeve. Naime, opće pravilo sadržano u preporuci EK-a pogodno je za sprječavanje onih oblika aktivnosti poreznih obveznika koji predstavljaju očite zloporabe. Predvidivi problemi pri tumačenju i primjeni općeg pravila od strane poreznih tijela mogli bi dijelom biti otklonjeni praksom CJEU-a. Stoga smatramo kako takvo opće pravilo ne bi imalo tek učinak odvraćanja, već bi se doista i primjenjivalo u praksi. Ovlaštenje poreznih tijela za nametanje poreza u skladu sa stvarnim ekonomskim sadržajem aktivnosti poreznih obveznika jasno slijedi ciljeve porezne pravednosti i učinkovitosti. Pritom ne treba zanemariti potencijalne pozitivne fiskalne učinke koherentnog okvira za sprječavanje izbjegavanja poreza, čiji je oslonac upravo opće pravilo.

Smatramo kako uvođenje predloženog općeg pravila može voditi i ostvarenju još jednog važnog cilja, povećanju konkurentnosti hrvatskog poreznog sustava. Naime, takvo bi pravilo osiguralo uniforman pristup poreznih tijela i sudova svim aktivnostima poreznih obveznika, bez obzira je li riječ o unutarnacionalnim ili prekograničnim situacijama. Hrvatska bi tako imala jednostavniji i atraktivniji pravni okvir u odnosu na druge države članice EU-a (za primjer Italije vidi supra, poglavlje 3.3.). To ima posebno značenje u vrijeme kada se države sve više oslanjaju na elemente poreznih sustava pri privlačenju stranih ulaganja. Pritom je nužna i određena doza opreza. Naime, mogući učinak zakonodavnih promjena u području izbjegavanja poreza na opseg stranih ulaganja je teško predvidjeti. Ulagači mogu negativno reagirati na uvođenje strožih i nedovoljno jasnih pravila, kao što pokazuje primjer rasprave o uvođenju općeg pravila u porezni sustav Indije (Devi Ravi, 2OI2.).

\section{ZAKLJUǦAK}

Svjetski trendovi ukazuju na sve veće značenje problema zakonitog izbjegavanja porezne obveze i mogućih odgovora poreznih vlasti. Očekuje se da će ovo pitanje i u narednom razdoblju ostati u žarištu porezne politike, bar dok se ne iznađu uspješni modeli za suprotstavljanje onim oblicima izbjegavanja poreza koji iskorištavaju izostanak porezne koordinacije između država. Mnoge su se države odlučile za uporabu različitih pravnih instrumenata s ciljem sprječavanja izbjegavanja poreza i zaštite vlastite porezne osnovice. U tom smislu ključno mjesto pripada općem pravilu protiv izbjegavanja poreza (GAAR). Njegova je temeljna funkcija u pojmovnom razgraničavanju prihvatljivog poreznog planiranja od neprihvatljivog izbjegavanja poreza, čime se promiče više ciljeva porezne politike.

Analiza iznesena u ovom radu ukazuje na nedostatak usmjerene i koherentne politike protiv zakonitog izbjegavanja poreza u Hrvatskoj. Hrvatski zakonodavac dosad nije prepoznao potrebu za uvođenjem općeg pravila. Mišljenja smo kako je pravi trenutak za promjenu pristupa jer bi uvođenje općeg pravila u skladu s preporukom Europske komisije moglo biti pogodno za ostvarenje nekoliko poželjnih ciljeva porezne politike. Ostvarenje načela pravne sigurnosti, zajedno s ustavnim načelom porezne pravednosti, ono je čemu nositelji porezne politike moraju težiti u narednom razdoblju. Uvođenjem predloženog općeg pravila pravna se sigurnost može uvećati, ponajprije zbog moguće uloge prakse CJEU-a u tumačenju nedoumica u njegovoj primjeni. Predloženim se zakonskim promjenama promiču i drugi ciljevi, poput porezne pravednosti, učinkovitosti, povećanja poreznih prihoda te porezne konkurentnosti. U svjetlu aktualnih problema s kojima se hrvatsko gospodarstvo suočava, ne treba zanemariti moguću ulogu stvaranja koherentnog normativnog okvira protiv izbjegavanja poreza. To je nužni dio politike smanjenja poreznog jaza i stvaranja održivog sustava javnih financija. Opće je pravilo neizostavni dio takvog normativnog okvira, što potvrđuju i iskustva drugih država. 


\section{REFERENCE}

I. Alm, J., 20I2. Measuring, explaining, and controlling tax evasion: lessons from theory, experiments, and field studies. International Tax and Public Finance, I9(I), str. 54-77. doi: I0.IO07/sIO797-OII-9I7I-2

2. Andreoni, J., Erard B. i Feinstein, J., 1998. Tax Compliance. Journal of Economic Literature, 36(2), str. 8I8-860.

3. Arbutina, H. [et al.], 20I4. (forthcoming). Trends and Players in Tax Policy - National Report Croatia.

4. Arnold, B., 2008. A comparison of statutory general anti-avoidance rules and judicial general antiavoidance doctrines as a means of controlling tax avoidance: Which is better? (What would John Tiley think?). In: Avery Jones, J., Harris, P., Oliver, D., Comparative Perspectives on Revenue Law: Essays in Honour of John Tíley. Cambridge: Cambridge University Press, str. I-24. doi: IO.IOI7/CBO9780511585951.003

5. Atkinson, C., 2OI2. General anti-avoidance rules: Exploring the balance between the taxpayer's need for certainty and the government's need to prevent tax avoidance. Journal of Australian Taxation, I4(I), str. I-56.

6. Avery Jones, J., I996. Tax Law: Rules or Principles? Fiscal Studies, I7(3), str. 63-89. doi: Io.IIII/j.I4755890.I996.tboo494.X

7. Avi Yonah, R., 2006. The Three Goals of Taxation. Tax Law Review, 6o(I), str. I-28.

8. Aviani, D. i Đerđa, D., 2OI2. Uniformno tumačenje i primjena prava te jedinstvenost sudske prakse u upravnom sudovanju. Zbornik radova Pravnog fakulteta u Splitu, 49(2), str. 369-394.

9. Barker, W. B., 2009. The Ideology of Tax Avoidance. Loyola University Chicago Law Journal, 40(2), str. 229-252.

Io. Bejaković, P., 2009. Tax Evasion, State Capacity and Trust in Transitional Countries: the Case of Croatia. Društvena istraživanja, I8(4-5), str. 787-806.

II. Braithwaite, J., 2002. Rules and Principles: A Theory of Legal Certainty. Australian Journal of Legal Philosophy, 27, str. 47-82,

I2. Brown, K., 20I2. Comparative Regulation of Corporate Tax Avoidance: An Overview. In: Brown, K., ed. A Comparative Look at Regulation of Corporate Tax Avoidance. Dordrecht: Springer, str. I-24. doi: I0.1007/978-94-007-2342-9_I

13. Clifford Chance, 2013. Tackling tax avoidance: a comparative study of general anti-abuse rules across Europe. Dostupno na: <http://www.cliffordchance.com/briefings/2013/o6/tackling_tax_avoidanceacomparativestudyo.html $>$.

I4. Cooper, G., 200I. International Experience with General Anti-Avoidance Rules. S.M.U. Law Review, 54(I), str. 83-I3O.

15. Cordeiro Guerra, R. i Mastellone, P., 2009. The Judicial Creation of a General Anti-Avoidance Rule Rooted in the Constitution. European Taxation, 49(II).

I6. Council Directive 2003/49/EC of 3 June 2003 on a common system of taxation applicable to interest and royalty payments made between associated companies of different Member States (Interest and Royalty Directive).

17. Council Directive 90/434/EEC of 20 August 1990 on the common system of taxation applicable to mergers, divisions, transfers of assets and exchanges of shares concerning companies of different member states (Merger Directive).

18. Council Directive 90/435/EEC of 23 July 1990 on the common system of taxation applicable in the case of parent companies and subsidiaries of different member states (Parent-Subsidiary Directive)

19. Court of Justice of the European Union, 2006a, C-255/O2 Halifax [2006] ECR I-oI6o9.

20. Court of Justice of the European Union, 2006b, C-I69/O4 Cadbury Schweppes [2006] ECR I-4O27.

2I. Dahlberg, M., 2007. The European Court of Justice and Direct Taxation: A Recent Change of Direction? In: K. Andersson, E. Eberhartinger and L. Oxelheim, eds. National Tax Policy in Europe. Berlin: Springer, str. 165-190. doi: Io.I007/978-3-540-707II-O_7

22. De Monès, S. [et al], 20Io. Abuse of Tax Law across Europe. EC Tax Review, 19(2-3).

23. Devi Ravi, B., 20I2. Is GAAR a hindrance to FDI? Dostupno na: <http://www.newindianexpress.com/education/student/articlei23730I.ece>.

24. Dworkin, R., 1978. Taking Rights Seriously. Cambridge: Harvard University Press.

25. Edgar, T., 2008. Building a Better GAAR. Virginia Tax Review, 27(4), str. 833-905.

26. Ernst\&Young, 20I3. GAAR Rising: Mapping tax enforcement's evolution. Dostupno na: 〈http://www.ey.com/Publication/vwLUAssets/GAA_rising/\$FILE/GAAR_rising_I\%2OFeb_2OI3.pdf >.

27. European Commission, 2012. Commission Recommendation on aggressive tax planning, C (2OI2) 8806 final.

28. Faulhaber, L., 20Io. Sovereignty, Integration and Tax Avoidance in the European Union: Striking the Proper Balance. Columbia Journal of Transnational Law, 48(2), str. 177-24I. 
29. Fernandes Ferreira, R. M., Respício Gonçalves, M. i Bordalo e Sá, L., 20II. General Anti-Avoidance Clause: the first judicial decision. Tax Information PLMJ, 2I(June), str. I-2.

30. Freedman, J. 20I2. GAAR as a process and the process of discussing the GAAR. British Tax Review, I2, str. 22-27.

3I. Freedman, J., 2004. Defining Taxpayer Responsibility: In Support of a General Anti-Avoidance Principle. British Tax Review, 4, str.332-357.

32. Garbarino, C., 2012. Italy. In: Brown, K., ed. A Comparative Look at Regulation of Corporate Tax Avoidance. Dordrecht: Springer, str. 197-222. doi: Io.IOO7/978-94-007-2342-9_9

33. Hillman, A. L., 2009. Public Finance and Public Policy: Responsibilities and Limitations of Government. Cambridge: Cambridge University Press.

34. Hyman, D., 2011. Public Finance: A Contemporary Application of Theory to Policy. Mason: Cengage Learning.

35. IMF, 20I3. Fiscal Monitor - Taxing Times. Washington: International Monetary Fund.

36. International Tax Compact, 20Io. Addressing tax evasion and tax avoidance in developing countries. Eschborn: Deutsche Gesellschaft fur Internationale Zusammenarbeit. Dostupno na: <http://www.taxcompact.net/documents/2OII-o9-o9_GTZ_Addressing-tax-evasion-and-avoidance.pdf>.

37. Jimenez, A. M., 20I2. Towards a Homogeneous Theory of Abuse in EU (Direct) Tax Law. Bulletin for International Taxation, 66(4/5), str. 270-292.

38. Jozipović, Š., 20I3. Tendencies in Croatian Tax Law regarding CFC Legislation. European Tax Studies, $\mathrm{I}(\mathrm{I})$, str. I-Ig.

39. Kapetanović, S., 20Io. Prividni pravni poslovi, Porezni vjesnik, 3, str. 40-46.

40. KPMG, 2013. Croatia country profile. Dostupno na: <http://www.kpmg.com/Global/en/services/Tax/regional-tax-centers/european-union-tax-centre/Documents/eu-countryprofiles/2013-croatia.pdf>.

4I. Lampreave, P., 2012. An Assessment of Anti-Tax Avoidance Doctrines in the United States and the European Union. Bulletin for International Taxation, 66(3), str. I53-I69.

42. Lyons, T., 20I3. The financial crisis, tax avoidance and an EU GAAR British Tax Review, 2, str. III-II7.

43. McGee, R. W. i Tyler, M., 2006. Tax Evasion and Ethics: A Demographic Study of 33 Countries. Dostupno na: 〈http://ssrn.com/abstract $=940505>$.

44. Opći porezni zakon, NN I47/o8, I8/II, 78/I2, I36/I2, 73/I3. Zagreb: Narodne novine.

45. Ostwal, P. i Vijayaraghavan, V., 20IO. Anti-Avoidance Measures. National Law School of India Review, 22(2), str. 59-IO3.

46. Perrou, K., 2006. The Judicial Application of Anti-Avoidance Doctrines in Greece and its Impact on International Tax Law Intertax, 34(2), str. IOI-III.

47. Pistone, P., 2008. European direct tax law: quo vadis? In: Hinnekens, L., Hinekkens, P., eds. A vision of taxes within and outside European borders: Festschrift in honor of Prof. Dr. Frans Vanistendael. Alphen aan den Rijn: Kluwer.

48. Pravilnik o porezu na dobit, NN 95/O5, I33/O7, I56/O8, I46/O9, I23/IO, I37/II, 6I/I2, I46/I2, I60/I3, I2/I4. Zagreb: Narodne novine.

49. Prebble, R. i Prebble, J., 20IO. Does the Use of General Anti-Avoidance Rules to Combat Tax Avoidance Breach Principles of the Rule of Law? Saint Louis University Law Journal 55(I), str. 2I-46.

50. Prebble, R., 2005. Does Croatia Need a General Anti-Avoidance Rule? Recommended Changes to Croatia's Current Legislative Framework. Financial Theory and Practice, 29(3), str. 2II-227.

5I. Prebble, Z. i Prebble, J., 2008. Comparing the Anti-Avoidance Rule of Income Tax Law with the Civil Law Doctrine of Abuse of Law. Bulletin for International Taxation, 62(4), str. I5I-I70.

52. Rogić Lugarić, T. i Bogovac, J., 2OI2. Pravni status poreznih izdataka: stanje i perspective. In V. Bratić and M. Fabris, eds. Zbornik radova Skrivena javna potrošnja: sadašnjost i budućnost poreznih izdataka. Zagreb: Institut za javne financije, str. 175-196.

53. Ruiz Almendral, V., 2005. Tax Avoidance and the European Court of Justice: What is at Stake for European General Anti-Avoidance Rules? Intertax, 33(I2), str. 560-582.

54. Ruiz Almendral, V., 2013. Tax Avoidance, the "Balanced Allocation of Taxing Powers" and the Arm's Length Standard: an odd Threesome in Need of Clarification. In: Richelle, I., Schön W. and Traversa, E., eds. Allocating Taxing Powers within the European Union. Dordrecht: Springer, str. I3I-170. doi: I0.1007/978-3-642-34919-5_7

55. Russo, R., 2007. Fundamentals of international tax planning. Amsterdam: IBFD.

56. Santiago, B., Salema, I. i Carvalho Nunes, R., 20II. Updates on Intercorporate Dividends, GAAR, Arbitration. Journal of International Taxation, Dateline Portugal, io (October), str. 59-61. 
57. Schön, W., 2008. Abuse of rights and European tax law. In: Avery Jones, J., Harris, P., Oliver, D. Comparative Perspectives on Revenue Law: Essays in Honour of John Tiley. Cambridge: Cambridge University Press, str. 75-98.

58. Schön, W., 20I3. Transfer Pricing, the Arm's Length Standard and European Union Law. In: Richelle, I., Schön W. i Traversa, E., eds. Allocating Taxing Powers within the European Union. Dordrecht: Springer, str. 73-100. doi: 10.1017/CBO9780511585951.006

59. Šimović, J. [et al.], 20Io. Hrvatski fiskalni sustav. Zagreb: Narodne novine.

6o. Sinfield, G., 20II. The Halifax principle as a universal GAAR for tax in the EU. British Tax Review, 3, str. 235-246. doi: I0.IOO7/978-3-642-34919-5_4

6I. Slemrod, J. i Yitzhaki, S., 2002. Tax avoidance, evasion, and administration. In: Auerbach, A. and Feldstein, M., eds. Handbook of Public Economics. Amsterdam: Elsevier, str. I423-I470.

62. Soler Roch, M. T., 2004. The Reform of a Tax Code: The Experience of the Spanish General Tax Act (Ley General Tributaria). British Tax Review, 4, str. 234-247.

63. Soler Roch, M. T., 2012. Forum: Tax Administration versus Taxpayer - A New Deal? World tax journal, 4(3), str. 282-296.

64. Stathis, D., 2013. Greece: New Greek Income Tax Code is supplemented by additional anti avoidance rules. International Tax Review. Dostupno na: <http://www.internationaltaxreview.com/Article/3245022/Greece-New-Greek-Income-Tax-Code-is-supplemented-by-additional-antiavoidance-rules.html $>$.

65. Tax Law Review Committee, 1997. Tax Avoidance. London: Institute for Fiscal Studies.

66. Terra, B. i Wattel, P., 2012. European Tax Law. Alphen aan den Rijn: Kluwer.

67. Thurony, V., 2003. Comparative tax law. Alphen aan den Rijn: Kluwer.

68. Tooma, R. A., 2008. Legislating Against Tax Avoidance. Amsterdam: IBFD.

69. Torgler, B. i Schaltegger, C., 2005. Tax Morale and Fiscal Policy. CREMA Working Paper, 2005-30. Dostupno na: <www.yale.edu/leitner/resources/docs/taxmorale.pdf $>$.

70. Tyson, J., 20I4. Reforming Tax Expenditures in Italy: What, Why, and How? Dostupno na: 〈http://www.imf.org/external/pubs/ft/wp/2014/wpI407.pdf〉.

7I. Uckmar, V., I983. Tax avoidance/Tax evasion: General report. In: IFA Cahiers de Droit Fiscal International 68a. Alphen aan den Rijn: Kluwer.

72. Ustav Republike Hrvatske, NN 56/90, I35/97, 8/98, II3/OO, I24/OO, 28/OI, 4I/OI, 55/OI, 76/IO, 85/Io. Zagreb: Narodne novine.

73. Vanistaendel, F., 1996. Legal Framework for Taxation. In: Thurony, V. ed. Tax Law Design and Drafting (vol. I). Washington: International Monetary Fund.

74. Weber, D., 2005. Tax Avoidance and the EC Treaty Freedoms: A Study on the Limitations Under European Law to the Prevention of Tax Avoidance. Alphen aan den Rijn: Kluwer.

75. Weisbach, D. A., 2002. An Economic Analysis of Anti-Tax Avoidance Doctrines. University of Chicago Law School, John M. Olin Law \& Economics Working Paper No. 99. Dostupno na: $\langle$ http://papers.ssrn.com/sol3/papers.cfm?abstract_id=228536〉.

76. Zakon o poreznoj upravi, NN $148 /$ I3. Zagreb: Narodne novine.

77. Zakon o porezu na dobit, NN I77/O4, 90/O5, 57/o6, I46/O8, 80/IO, 22/I2, I48/I3. Zagreb: Narodne novine.

78. Zimmer, F., 2002. Form and substance in tax law: General report. In: IFA Cahiers de Droit Fiscal International 89a. Alphen aan den Rijn: Kluwer.

79. Zolo, D., 2007. The Rule of Law: A Critical Reappraisal. In: Costa, P. and Zolo, D., eds. The Rule of Law: History, Theory and Criticism. Dordrecht: Springer, str. 3-7I.

8o. Žunić Kovačević, N. i Gadžo, S., 2013. Institut zakonskog poreznog jamstva nakon novele Općeg poreznig zakona 20I2.: "Proboj pravne osobnosti” trgovačkih društava u slučaju zlouporabe prava. Zbornik Pravnog fakulteta u Rijeci, 34(I), str. 393-4I6. doi: I0.IO07/978-3-642-35697-I_5

8I. Žunić Kovačević, N., 2OI2. Croatia. In K. Brown, ed. A Comparative Look at Regulation of Corporate Tax Avoidance. Dordrecht: Springer, str. I23-I30.

82. Žunić Kovačević, N., 20I3. Coordinating Taxation Between the European Union and Other Countries Through Advance Tax-Rulings Systems. In: Peeters, M., Sabri, N. and Shahin W., eds. Financial Integration: A Focus on the Mediterranean Region. Dordrecht: Springer, str. 87-94. doi: I0.1007/978-94-007-2342-9_5 